\title{
Fertilization with Nitrogen, Phosphorus and Potassium in Upland Rice Cultivars in the Southern Region of Rondônia, Brazil
}

\author{
Edimar Rodrigues Soares ${ }^{1}$, Robertt Fernandes ${ }^{2}$, Laércio da Silva Londero ${ }^{3}$, \\ Leandro Galon ${ }^{4}$, Fabiana Ferreira Pires ${ }^{5}$, Marcelo de Andrade Barbosa1, \\ Diego Lopes dos Santos' ${ }^{3}$, Samara Cristina Sampaio Correa ${ }^{3}$, \\ Everton Augusto Sampaio Correa ${ }^{3}$, Remy Carvalho dos Santos ${ }^{3}$ \\ ${ }^{1}$ Department of Soil Science, São Paulo State University (UNESP), Jaboticabal, Brazil \\ ${ }^{2}$ Department of Agronomy, Federal Institute of Education Science and Technology of Rondônia (IFRO), \\ Colorado do Oeste, Brazil \\ ${ }^{3}$ Department of Agronomy, College Amazon (FAMA), Vilhena, Brazil \\ ${ }^{4}$ Department Herbology, Federal University of the Border South (UFFS), Erechim, Brazil \\ ${ }^{5}$ Federal University Mato Grosso (UFMT), Cuiaba, Brazil \\ Email: *soares-agro@hotmail.com
}

Received 18 July 2015; accepted 7 September 2015; published 10 September 2015

Copyright (C) 2015 by authors and Scientific Research Publishing Inc.

This work is licensed under the Creative Commons Attribution International License (CC BY).

http://creativecommons.org/licenses/by/4.0/

(c) (i) Open Access

\section{Abstract}

The upland rice productivity in the state of Rondônia is still low, in view of the potential of culture. The use of cultivars adapted to different regions and more responsive to fertilizer employed is an essential practice which can change that. The aim of this study was to evaluate the agronomic characteristics and productivity of two upland rice cultivars with nitrogen, phosphorus and potassium (N-P-K) doses in two municipalities in the southern state of Rondonia region. The experimental design was a randomized block design with four replications in a factorial $2 \times 2 \times 5$, with the first factor composed of two cultivars (hybrid Ecco and conventional farming AN Cambará), the second factor, the environment of the two municipalities, Cerejeiras and Vilhena and the third factor of five doses of N-P-K (0-0-0, 30-40-30, 60-60-60, 90-90-90 and 120-100-120 kg-ha-1). The characteristics evaluated were: tillering, number of integers and sterile grains per panicle, weight of 1000 grains, grain yield $\left(\mathrm{kg} \cdot \mathrm{ha}^{-1}\right)$ and whole grain yield. There was no triple interaction between the three factors for any of the traits. The hybrid Ecco has higher tillering ability than AN Cambara and presents fewer sterile grains per panicle, heavier 1000 grains and hence greater productivity. For both cultivars, the highest yields are obtained with a dose of $120-100-120 \mathrm{~kg} \cdot \mathrm{ha}^{-1} \mathrm{~N}-\mathrm{P}-\mathrm{K}$. For the Ecco, the productivity is achieved with this dose and the dose of $90-90-90 \mathrm{~kg}^{-h^{-1}}$ is sta- $^{-}$

\footnotetext{
${ }^{*}$ Corresponding author.

How to cite this paper: Soares, E.R., Fernandes, R., da Silva Londero, L., Galon, L., Pires, F.F., de Andrade Barbosa, M., dos Santos, D.L., Correa, S.C.S., Correa, E.A.S. and dos Santos, R.C. (2015) Fertilization with Nitrogen, Phosphorus and Potassium in Upland Rice Cultivars in the Southern Region of Rondônia, Brazil. American Journal of Plant Sciences, 6, $2263-2271$. http://dx.doi.org/10.4236/ajps.2015.614229
} 
tistically similar. There is no difference in productivity between the municipalities when the dose of N-P-K is less than $60-60-60 \mathrm{~kg}^{-h a^{-1}}$. The highest yield of whole grains in function of N-P-K fertilization is obtained in Cerejeiras.

\author{
Keywords
}

Oryza sativa L., Productivity, Hybridization

\title{
1. Introduction
}

The upland rice is an important culture in cultivation systems in South America. In this scenario, Brazil stands out as the largest producer [1]. The upland rice cultivation is characterized by aerobic condition root development of the plant [2]. This system is made in well-drained soil without water accumulation in the field, so the culture depends entirely on rain water for the water necessary for their development [3].

The Rio Grande do Sul is responsible for $67 \%$ of Brazilian production of rice, which is grown in irrigated system [4]. However, in others states most of the rice-growing is done in the dry system, mainly in central Brazil, known as cerrado.

In the state of Rondônia (RO) municipalities of Cabixi, Vilhena, São Francisco do Guaporé, Cerejeiras, Corumbiara, Ariquemes, Castanheiras, Buritis, São Felipe d'Oeste and Pimenteiras do Oeste are the largest producers of rice, accounting for $51 \%$ of production state [5]. In recent years, with the decline of the agricultural frontier, the upland rice, which has long been known as culture of openness, it has occupied new spaces. The crop is being used as a part of rotation systems with other crops, such as soybeans, and also pastures [6].

The upland rice was highlighted as a pioneer culture in clearing the Brazilian cerrado. At that time (the 1970s), productivity was very low, rarely exceeded $1.5 \mathrm{Mg} \cdot \mathrm{ha}^{-1}$, mainly due to low technology applied [5]. Currently, the productivity of upland rice in RO is $2.8 \mathrm{Mg}$ per hectare. This production is much lower than that achieved by

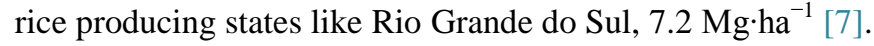

According to [6], despite the two cropping systems (rainfed and irrigated) are very different, it is not impossible that the upland rice also reach productivity similar to irrigated. However, some factors must be taken into account to achieve the desired productivity.

An alternative to increasing the productivity of upland rice is the use of hybrid cultivars. However, research on hybrid cultivars of upland rice in Brazil is still rare. According to [8], these cultivars have better development of root system and increased tillering, resulting in obtaining higher yields. [8] and [9] reported productivities with upland rice hybrid of 6.7 to $4.6 \mathrm{Mg} \cdot \mathrm{ha}^{-1}$, respectively. Working with conventional cultivars [10] [11] also achieved yields around 4 - $5 \mathrm{Mg}$ per hectare. Therefore, the choice of suitable cultivation for each region is an extremely important step.

Another factor to be taken into consideration is the response of cultivars the level of technology employed, for example, the yield obtained as a function of applied nutrients such as nitrogen, phosphorus and potassium. Whereas most of the cerrado soils are Oxisols and Ultisols that, in general, are acidic and have low nutrient content [3]. It should be noted also that rice is also being used in the recovery of degraded pastures, and as the first crop to be installed in this recovery process. This becomes even more important employment of N-P-K fertilization and the ability of the cultivars to take advantage of these nutrients.

Therefore, the aim of this study was to evaluate the agronomic characteristics and productivity of two upland rice cultivars, with a hybrid and conventional farming with N-P-K doses in two cities in the southern state of Rondônia region.

\section{Material and Methods}

The experiments were conducted in the agricultural year 2010/2011 in the municipalities of Vilhena and Cerejeiras, south of the state of Rondonia. In Vilhena, the test was conducted at the Experimental Farm of the University of Amazon, located at a latitude S12 $44^{\prime} 26^{\prime \prime}$ and a longitude $60^{\circ} 08^{\prime} 45^{\prime \prime} \mathrm{W}$, altitude of $612 \mathrm{~m}$. In Cerejeiras, the experiment was also conducted in the University of Amazon on the Experimental Field, with an altitude of $257.8 \mathrm{~m}, 13^{\circ} 11^{\prime} 19.6^{\prime \prime S}$ latitude and $60^{\circ} 51^{\prime} 43.9^{\prime \prime} \mathrm{W}$ longitude. The precipitation in southern Rondonia 
are regular averaging $2023 \mathrm{~mm}$ in the period from October to June, when the crop cultivation is performed, with emphasis on the soybean, rice and corn. During this period temperatures are favorable to agriculture Also, ranging from $22.1^{\circ} \mathrm{C}$ to $25.4^{\circ} \mathrm{C}$ [12].

The experimental design was a randomized block design with four replications in a factorial $2 \times 2 \times 5$, with the first factor composed of two cultivars (hybrid Ecco and conventional farming AN Cambará), the second factor for the environment, which are the municipalities of Cerejeiras and Vilhena and the third factor of five doses of N-P-K (0-0-0, 30-40-30, 60-60-60, 90-90-90 and 120-100 -120 kg.ha $\left.{ }^{-1}\right)$.

The experimental units were comprised of the area of $5 \times 2.0 \mathrm{~m}\left(10 \mathrm{~m}^{2}\right)$, this being sown eight lines of $5 \mathrm{~m}$ in length, spaced at $0.25 \mathrm{~m}$ between rows. To harvest was discarded two border lines and $0.5 \mathrm{~m}$ from each end portion. The chemical characteristics of the soils in the municipalities of Cerejeiras and Vilhena in the $0-20 \mathrm{~cm}$ layer are presented in Table 1.

The soils were prepared in conventional farming system using disc harrow and leveling. Liming was performed with calcined limestone (48\% Ca oxide, $16 \% \mathrm{Mg}$ oxide and relative power of total neutralization of 124\%) 40 days before planting, seeking to raise the base saturation to $50 \%$. Planting was carried out in December 2010. The density of used sowing was $40 \mathrm{~kg} \cdot \mathrm{ha}^{-1}$ for cultivating hybrid Ecco and $80 \mathrm{~kg} \cdot \mathrm{ha}^{-1}$ for conventional farming AN Cambara.

The phosphor was applied on the whole planting along with 30\% potassium and $30 \%$ nitrogen. In topdressing (20 days after emergence) was applied $60 \%$ of nitrogen and potassium and in the issue of panicles the remaining $10 \%$. The sources of fertilizer are used, the single superphosphate $(19 \% \mathrm{P})$, urea $(45 \% \mathrm{~N})$ and potassium potash (65\% K).

The weed control was made 25 days after emergence with application of cyhalofop-butyl herbicide $\left(1.5 \mathrm{~L} \cdot \mathrm{ha}^{-1}\right)$ and Metsulfurom-methyl $\left(3 \mathrm{~g} \cdot \mathrm{ha}^{-1}\right)$. The disease control was done with fungicide tricyclazole $\left(300 \mathrm{~g} \cdot \mathrm{ha}^{-1}\right)+$ Tebuconazole $\left(750 \mathrm{~mL} \cdot \mathrm{ha}^{-1}\right)$ - at 50, 70 and 85 days after emergence; and insect control with a permethrin insecticide application base $\left(150 \mathrm{~mL} \cdot \mathrm{ha}^{-1}\right)$ at 15 days after emergence.

The following characteristics were evaluated: tillering-performed at 35 days after emergence (maximum tillering), measured on the line on a meter; number of whole grains per panicle and sterile-for it was collected ten panicles randomly in each experimental unit; the 1000 seeds-numbered sample taken from each experimental unit; Grain yield $\left(\mathrm{kg} \cdot \mathrm{ha}^{-1}\right)$, and the mass of grains was adjusted to 13\% moisture, and whole grain yieldobtained from dairy apparatus (rice tester model PAZ-1DT). After obtaining the data, it carried out a preliminary analysis of variance (Test F) and then the unfolding of degrees of freedom treatments when there was interaction between the factors. Means were compared by the test "Tukey $(\mathrm{P}<0.05)$ " [13].

\section{Results and Discussion}

Tillering was influenced by the type of cultivar, environment and fertilizer. The interaction was significant for cultivar $\times$ environment, fertilization $\times$ cultivar and environment $\times$ fertilization, however, there was no triple interaction cultivar $\times$ environment $\times$ fertilization (Table 2). From Table 3, it is observed that, tillering hybrids Ecco was higher than AN Cambará for both two municipalities. For the Ecco tillering it was higher in the municipalitie of Cerejeiras, while for the AN Cambará no significant difference between the tested municipalities (Table 3).

With this, we can infer that to the cultivar AN Cambará the tillering is an intrinsic characteristic, occurring little environmental interference that feature, while the hybrid Ecco shows greater capacity to respond to environmental growing conditions. Observing Table 4, we can strengthen this hypothesis, as in all N-P-K combinations tested, the hybrid tillering surpassed the AN Cambara. It is noteworthy that for the AN Cambara was no significant difference between treatments without fertilizer (00-00-00) and 30-40-30, but with the Ecco was significant difference between treatments without fertilization, 30-40-30 and 60-60-60, demonstrating that responds better to fertilization with N-P-K.

To take into consideration that the hybrid seeding rate is $50 \%$ lower than that of conventional rice cultivars, it can be concluded that this has an excellent ability to tillering, given the best results in relation to AN Cambara (Table 3 and Table 4). [9] also reported the high capacity of tillering hybrid Ecco compared to conventional five cultivars: BRS Primavera, AN Cambara, BRS Monarca, BRS Sertaneja and BRS MG Curinga, and the two cultivars first mentioned, are the most planted in the state of Rondônia.

Regarding interaction environment $\times$ fertilization, there was only significant difference between the municipalities in the unfertilized treatment and with treatment 90-90-90 (Table 5). 
Table 1. Chemical characterization of soils of the municipalities used in the experiment.

\begin{tabular}{|c|c|c|c|c|c|c|c|c|c|c|c|}
\hline \multicolumn{12}{|c|}{ Cerejeiras } \\
\hline $\mathrm{pH} \mathrm{CaCl}{ }_{2}$ & O. M. ${ }^{1}$ & $\mathrm{P}$ & $\mathrm{K}$ & $\mathrm{Ca}$ & $\mathrm{Mg}$ & $\mathrm{H}+\mathrm{Al}$ & $\mathrm{CEC}^{2}$ & B.S. ${ }^{3}$ & \multicolumn{3}{|c|}{ Particle size $\left(\mathrm{g} \cdot \mathrm{dm}^{-3}\right)$} \\
\hline $0.01 \mathrm{~mol} \cdot \mathrm{L}^{-1}$ & $\mathrm{~g} \cdot \mathrm{dm}^{-3}$ & $\mathrm{mg} \cdot \mathrm{dm}^{-3}$ & \multicolumn{5}{|c|}{ mmolc $\cdot \mathrm{dm}^{-3}$} & $(\%)$ & Clay & Silt & Sand \\
\hline 4.7 & 20 & 6.9 & 1.2 & 16 & 5 & 3.7 & 61.6 & 37.6 & 200 & 80 & 720 \\
\hline \multicolumn{12}{|c|}{ Vilhena } \\
\hline $\mathrm{pH} \mathrm{CaCl}{ }_{2}$ & O. M. & $\mathrm{P}$ & K & $\mathrm{Ca}$ & $\mathrm{Mg}$ & $\mathrm{H}+\mathrm{Al}$ & CEC & B.S. & \multicolumn{3}{|c|}{ Particle size $\left(\mathrm{g} \cdot \mathrm{dm}^{-3}\right)$} \\
\hline $0.01 \mathrm{~mol} \cdot \mathrm{L}^{-1}$ & $\mathrm{~g} \cdot \mathrm{dm}^{-3}$ & $\mathrm{mg} \cdot \mathrm{dm}^{-3}$ & \multicolumn{5}{|c|}{ mmolc $\cdot \mathrm{dm}^{-3}$} & $(\%)$ & Clay & Silt & Sand \\
\hline 5.5 & 15 & 4.8 & 0.9 & 15 & 9 & 3 & 55.5 & 46 & 180 & 20 & 800 \\
\hline
\end{tabular}

${ }^{1}$ Organic matter, ${ }^{2}$ Cation exchange capacity e. ${ }^{3}$ Base saturation.

Table 2. Analysis of variance for the tillering characteristics (Perf), number of whole grains (GI), number of sterile (GE), 1000 grain weight (1000 G), yield (PROD) and yield of whole grains (RGI (\%)).

\begin{tabular}{cccccccc}
\hline \multirow{2}{*}{ Variation causes } & GL & \multicolumn{3}{c}{} & \multicolumn{3}{c}{ Mean square } \\
\cline { 3 - 7 } & & Perf & GI & GE & 1000 G & PROD. & RGI (\%) \\
\hline Cultivar (C) & 1 & $101,887.8^{* * *}$ & $12,186.9^{* *}$ & $413.9^{* *}$ & $45.63^{* *}$ & $30,239,767.1^{* *}$ & $1.16^{\text {ns }}$ \\
Environment (A) & 1 & $8140.6^{* *}$ & $3672.9^{* *}$ & $695.2^{* *}$ & $137.19^{* *}$ & $3,989,696.8^{* *}$ & $770.86^{* *}$ \\
Fertilization(AD) & 4 & $18,359.02^{* *}$ & $1525.2^{* *}$ & $13.4^{\text {ns }}$ & $8.44^{\text {ns }}$ & $12,276,983.7^{* *}$ & $770.86^{\text {ns }}$ \\
C $\times$ A & 1 & $1629.01^{*}$ & $163.4^{\text {ns }}$ & $52.6^{*}$ & $3.82^{\text {ns }}$ & $400,392^{\text {ns }}$ & $334.83^{* *}$ \\
C $\times$ AD & 4 & $2002.03^{* *}$ & $549.2^{*}$ & $5.5^{\text {ns }}$ & $3.27^{\text {ns }}$ & $1,013,915.5^{*}$ & $15.49^{\text {ns }}$ \\
A $\times$ AD & 4 & $923.8^{*}$ & $788.7^{* *}$ & $13.8^{\text {ns }}$ & $4.31^{\text {ns }}$ & $901,327.1^{*}$ & $36.19^{*}$ \\
C $\times$ A $\times$ AD & 4 & $154.5^{\text {ns }}$ & $44.5^{\text {ns }}$ & $10.1^{\text {ns }}$ & $1.67^{\text {ns }}$ & $107,823.3^{\text {ns }}$ & $36.19^{\text {ns }}$ \\
Block & 3 & $1037.5^{*}$ & $95^{\text {ns }}$ & $2.4^{\text {ns }}$ & $3.15^{\text {ns }}$ & $543,586.3^{\text {ns }}$ & $12.14^{\text {ns }}$ \\
Resídue & 57 & 352.2 & 156.8 & 8.6 & 5.42 & $284,028.3$ & 14.13 \\
\hline
\end{tabular}

${ }^{*}$ Significant at $(\mathrm{p}<0.05),{ }^{* *}$ Significant at $(\mathrm{p}<0.01),{ }^{\mathrm{ns}}$ not significant.

Table 3. Tillering of upland rice depending on the cultivar and growing environment.

\begin{tabular}{ccc}
\hline \multirow{2}{*}{ Cultivars } & \multicolumn{3}{c}{ Municípalities (Environment) } \\
\cline { 2 - 4 } & Cerejeiras & Vilhena \\
\hline Ecco & $177.95 \mathrm{aA}$ & $148.75 \mathrm{aB}$ \\
AN Cambará & $97.55 \mathrm{bA}$ & $86.4 \mathrm{bA}$ \\
\hline
\end{tabular}

Means followed by the same lower case letters in the columns and lines not statistically different (Tukey $\mathrm{P}<0.05$ ).

Table 4. Tillering of upland rice according to the cultivar and the doses of nitrogen, phosphorus and potassium (N-P-K).

\begin{tabular}{cccccc}
\hline \multirow{2}{*}{ Cultivars } & \multicolumn{5}{c}{ Doses de N-P-K $\left({\left.\mathrm{kg} \cdot \mathrm{ha}^{-1}\right)}\right.$} \\
\cline { 2 - 6 } & $00-00-00$ & $30-40-30$ & $60-60-60$ & $90-90-90$ & $120-100-120$ \\
\hline Ecco & $103 \mathrm{aD}$ & $134.37 \mathrm{aC}$ & $175.37 \mathrm{aB}$ & $190.12 \mathrm{aAB}$ & $213.87 \mathrm{aA}$ \\
AN Cambará & $59.25 \mathrm{bC}$ & $83.25 \mathrm{bBC}$ & $87.75 \mathrm{bB}$ & $108.62 \mathrm{bAB}$ & $121 \mathrm{bA}$ \\
\hline
\end{tabular}

Means followed by the same lower case letters in the columns and lines not statistically different (Tukey P $<0.05$ ).

Table 5. Tillering of upland rice according of the crop environment and doses of nitrogen, phosphorus and potassium (N-P-K).

\begin{tabular}{cccccc}
\hline \multirow{2}{*}{ Municipalities } & \multicolumn{5}{c}{ Doses de N-P-K $\left(\mathrm{kg}^{\circ} \mathrm{ha}^{-1}\right)$} \\
\cline { 2 - 6 } & $00-00-00$ & $30-40-30$ & $60-60-60$ & $90-90-90$ & $120-100-120$ \\
\hline Cerejeiras & $102.87 \mathrm{aD}$ & $114.12 \mathrm{aCD}$ & $138.75 \mathrm{aBC}$ & $162.75 \mathrm{aAB}$ & $170.25 \mathrm{aA}$ \\
Vilhena & $59.37 \mathrm{bD}$ & $103.5 \mathrm{aC}$ & $124.37 \mathrm{aBC}$ & $136 \mathrm{bB}$ & $164.62 \mathrm{aA}$ \\
\hline
\end{tabular}

Means followed by the same lower case letters in the columns and lines not statistically different (Tukey $\mathrm{P}<0.05$ ). 
All factors significantly influenced the number of whole grains per panicle, however, only there was a significant interaction for fertilization $\times$ cultivar and environment $\times$ fertilization. As there was no interaction cultivar $\times$ environment, these two factors will be assessed independently as shown in Figure 1.

The largest number of whole grains per panicle was obtained in the municipality of Vilhena and, with regard to cultivars, the AN Cambara stood out in relation to Ecco (Figure 1). Regarding the interaction cultivar $\mathrm{x}$ fertilization, unlike tillering, for this variable, the highest values observed in the treatments (fertilizer), were observed in cultivar AN Cambard (Table 6). Another important fact is that the Ecco the fertilizations did not affect the number of whole grains per panicle, however, for the AN Cambará only significant difference between the treatment 00-00-00 and the others, ie the number of grains whole per panicle was impaired only in the absence of fertilization, with no response due to higher doses of N-P-K.

When the treatments were employed 60-60-60, 90-90-90 and 120-100-120, the municipality of Vilhena provided to obtain more of whole grains per panicle (Table 7), compared to the municipality of Cerejeiras. Evaluating fertilization alone within each municipality in Cerejeiras no significant difference between any of the used fertilizers. In Vilhena 00-00-00 and 30-40-30 treatments had lower number of whole grains per panicle than when using larger doses of N-P-K.

The number of sterile grains per panicle was influenced by cultivar and environment (Table 1), also occurring interaction between these factors (Table 8). The cultivar AN Cambara had the highest number of sterile grain than Ecco in both municipalities. Therefore for the hybrid Ecco and for the AN Cambara, the lowest number of sterile grains were observed in the municipality of Cerejeiras. It is noteworthy, however, that for Ecco the differ-

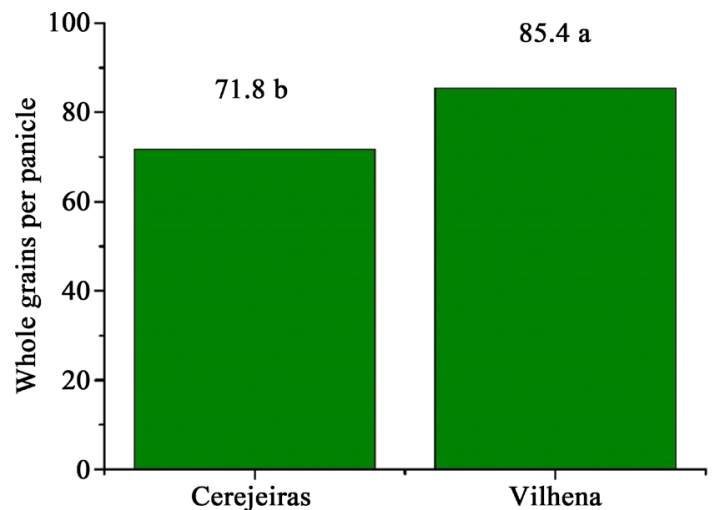

(a)

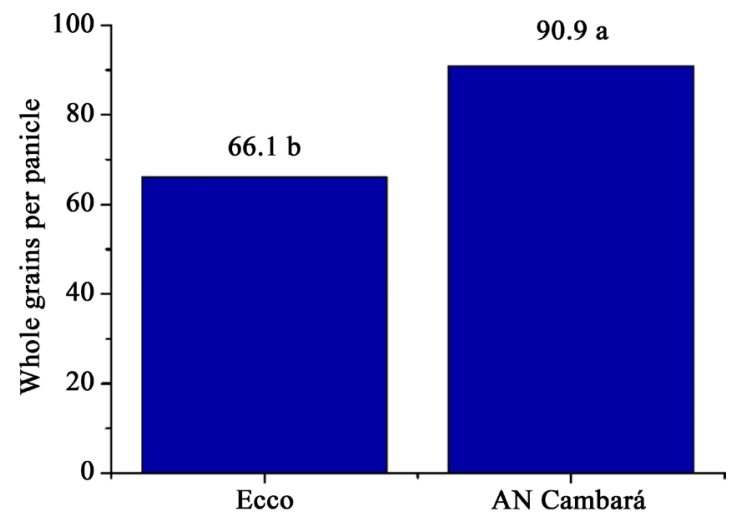

(b)

Figure 1. Number of whole grains per panicle according to the cultivated municipality (a) and cultivar (b). Means followed by the same letters are not statistically different (Tukey $\mathrm{P}<0.05$ ).

Table 6. Number of whole grains per panicle of rice upland according to the cultivar and doses of nitrogen, phosphorus and potassium (N-P-K).

\begin{tabular}{cccccc}
\hline \multirow{2}{*}{ Cultivars } & \multicolumn{5}{c}{ Doses of N-P-K $\left({\left.\mathrm{kg} \cdot \mathrm{ha}^{-1}\right)}^{-}\right.$} \\
\cline { 2 - 6 } & $00-00-00$ & $30-40-30$ & $60-60-60$ & $90-90-90$ & $120-100-120$ \\
\hline Ecco & $62.9 \mathrm{aA}$ & $58.1 \mathrm{bA}$ & $66.3 \mathrm{bA}$ & $70.2 \mathrm{bA}$ & $73.9 \mathrm{bA}$ \\
AN Cambará & $66.7 \mathrm{aB}$ & $87.7 \mathrm{aA}$ & $96.9 \mathrm{aA}$ & $99.01 \mathrm{aA}$ & $104.6 \mathrm{aA}$ \\
\hline
\end{tabular}

Means followed by the same lower case letters in the columns and lines not statistically different (Tukey P < 0.05).

Table 7. Number of whole grains per panicle of upland rice in according of the environment crop and doses of nitrogen, phosphorus and potassium (N-P-K).

\begin{tabular}{ccccc}
\hline \multirow{2}{*}{ Municipalities } & \multicolumn{3}{c}{ Doses of N-P-K $\left({\left.\mathrm{kg} \cdot \mathrm{ha}^{-1}\right)}\right.$} \\
\cline { 2 - 5 } & $00-00-00$ & $30-40-30$ & $60-60-60$ & $90-90-90$ \\
\hline Cerejeiras & $66.4 \mathrm{aA}$ & $72.6 \mathrm{aA}$ & $71.1 \mathrm{bA}$ & $74.4 \mathrm{bA}$ \\
Vilhena & $63.3 \mathrm{aB}$ & $73.1 \mathrm{aB}$ & $92.1 \mathrm{aA}$ & $94.8 \mathrm{aA}$ \\
\hline
\end{tabular}

Means followed by the same lower case letters in the columns and lines not statistically different (Tukey P $<0.05$ ). 
ence between the municipalities was much more relevant.

For Table 1, it can be noted that there is no interaction between any of the factors studied to 1000 grain weight, with only the cultivar and the environment interfered this characteristic. The municipality of Vilhena was responsible for the largest weight of 1000 grains (Figure 2(a)) and cultivar Ecco performed better, compared with AN Cambara (Figure 2(b)). Thus, there is the Ecco despite the lower number of whole grains per panicle observed compared to AN Cambara (Figure 1(b)), produces heavier grains and has a smaller loss of grain due to fewer previously reported sterile grains (Table 8).

As for productivity, this was significantly influenced by the type of the cultivar, the environment and fertilization. The interaction was significant for cultivar $\times$ fertilization and environment $\times$ fertilization. As there was no interaction cultivar $\times$ environment, is presented in Figure 3 the productivity in function of municipalities and cultivars separately. The highest yield was obtained in the municipality of Cerejeiras (Figure 3(a)) and

Table 8. Number of sterile grains per panicle rice upland depending on cultivar and growing environment.

\begin{tabular}{ccc}
\hline \multirow{2}{*}{ Cultivars } & \multicolumn{3}{c}{ Municipalities } & Vilhena \\
\cline { 2 - 3 } & Cerejeiras & $11.8279 \mathrm{bA}$ \\
Ecco & $4.3100 \mathrm{bB}$ & $14.7550 \mathrm{aA}$ \\
\hline
\end{tabular}

Means followed by the same lower case letters in the columns and lines not statistically different (Tukey P < 0.05).

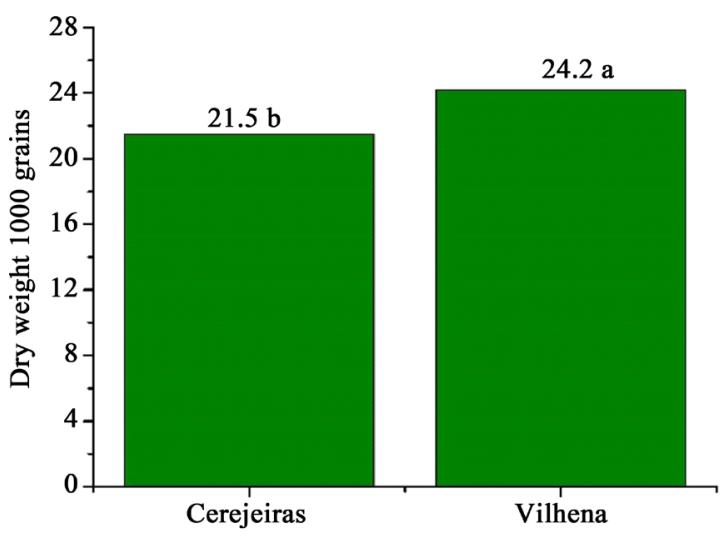

(a)

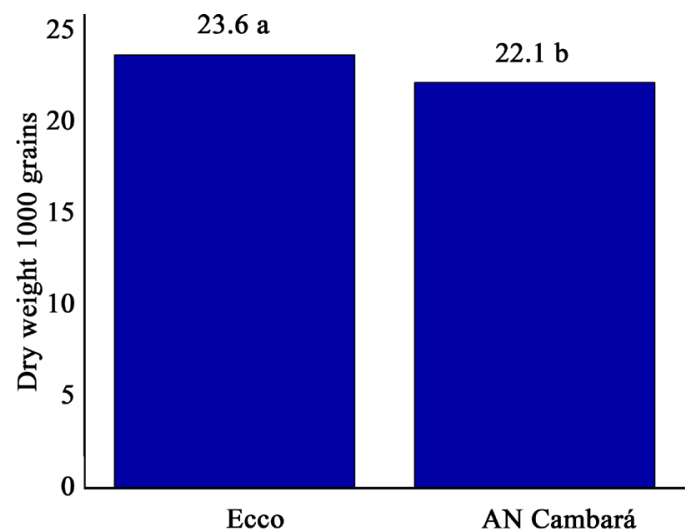

(b)

Figure 2. Weight of 1000 grains (g) per panicle according to the municipality grown (a) and of the cultivar (b). Means followed by the same letters are not statistically different (Tukey $\mathrm{P}<0.05$ ).

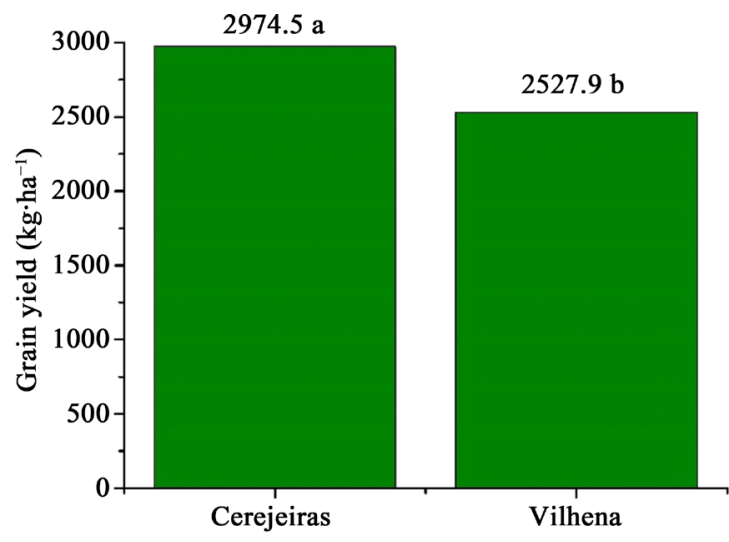

(a)

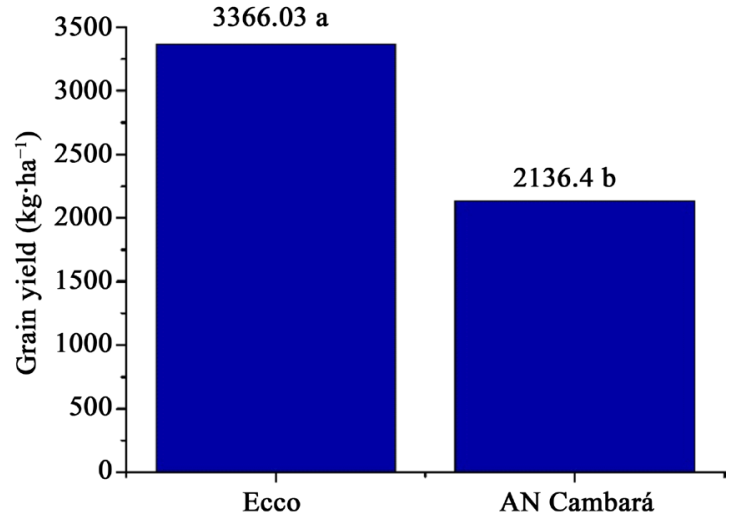

(b)

Figure 3. Productivity of rice grains upland according to the cultivated municipality (a) and cultivar (b). Means followed by the same letters are not statistically different (Tukey $\mathrm{P}<0.05$ ). 
cultivar Ecco was more productive, surpassing $1230 \mathrm{~kg} \cdot \mathrm{ha}^{-1}$ AN Cambara (Figure 3(b)). This higher productivity can be explained by the fact that cultivate it showed a higher tillering, associated with fewer sterile grains per panicle and higher 1000 grain weight, which probably outweigh the fewer whole grains presented by this cultivar.

Table 9 shows the interaction cultivar $\mathrm{x}$ fertilizer for grain yield. You can see that the productivity of Ecco was higher than AN Cambará in all tested fertilization. Individually, for the AN Cambara, there was no significant difference between treatments $00-00-00,30-40-30$ and 30-40-30 or between, 60-60-60 and 90-90-90, but with hybrid Ecco was significant difference between treatment 00-00-00, 30-40-30 and 60-60-60, demonstrating that this cultivar showed better responsiveness maids fertilization. As shown by [8], the hybrid ECOO is characterized by an excellent root development.

Remember that the global demand for food is expected to double in the coming decades, pressing farming systems to increase their productivity, and much of this increase will come from developing countries such as Brazil [14]. Thus, the selection of cultivars with desirable agronomic characteristics which have greater resistance to environmental changes and have higher capacity utilization of the applied inputs, is of fundamental importance in view of the growing scarcity of natural resources.

It is observed from Table 10 that only on $00-00-00$ and 30-40-30 treatments had significant difference between the municipalities of Cerejeiras and Vilhena, and with higher doses of N-P-K, the yields were similar. According to [15], proper fertilization can increase by up to $40 \%$ upland rice productivity in the cerrado soils, if other factors are not limiting. In the case of this study, the increase in productivity due to the higher dose of N-P-K compared to control (00-00-00) was 155\% for Ecco and 142\% for the AN Cambara.

As for the performance of whole grains in Cerejeiras the hybrid Ecco was higher than AN Cambara. In Vilhena was the reverse, with the AN Cambará getting higher yield of whole grains (Table 11). Note also that individually for Ecco the municipality interfered significantly in yield of whole, with best results observed in Cerejeiras, while for the AN Cambará the means were statistically similar in both cities.

In Table 12, it is observed that in general, the averages in the municipality of Cerejeiras were higher than the municipality of Vilhena. However, it appears that the N-P-K doses did not affect the yield of whole grains alone within each municipality.

Table 9. Productivity of grains of rice upland according on the cultivar and doses of nitrogen, phosphorus and potassium (N-P-K).

\begin{tabular}{|c|c|c|c|c|c|}
\hline \multirow{2}{*}{ Cultivars } & \multicolumn{5}{|c|}{ Doses of N-P-K $\left(\mathrm{kg} \cdot \mathrm{ha}^{-1}\right)$} \\
\hline & $00-00-00$ & $30-40-30$ & $60-60-60$ & $90-90-90$ & $120-100-120$ \\
\hline Ecco & $1821.04 \mathrm{aD}$ & $2737 \mathrm{aC}$ & $3612.05 \mathrm{aB}$ & 4022.5 аAB & $4637.58 \mathrm{aA}$ \\
\hline AN Cambará & 1283.37 bC & 1864 bBC & 2150.5 bB & $2282.90 \mathrm{bB}$ & 3101.25 bA \\
\hline
\end{tabular}

Means followed by the same lower case letters in the columns and lines not statistically different (Tukey P < 0.05).

Table 10. Productivity of grains of rice upland according to the cultivation environment and doses of nitrogen, phosphorus and potassium (N-P-K).

\begin{tabular}{ccccc}
\hline \multirow{2}{*}{ Municipalities } & \multicolumn{3}{c}{ Doses of N-P-K $\left({\left.\mathrm{kg} \cdot \mathrm{ha}^{-1}\right)}\right.$} \\
\cline { 2 - 5 } & $00-00-00$ & $30-40-30$ & $60-60-60$ & $90-90-90$ \\
Cerejeiras & $2119 \mathrm{aC}$ & $2668.5 \mathrm{aBC}$ & $3009.5 \mathrm{aB}$ & $3187.7 \mathrm{aAB}$ \\
Vilhena & $985.42 \mathrm{bD}$ & $1932.5 \mathrm{bC}$ & $2753.1 \mathrm{aB}$ & $3117.7 \mathrm{aAB}$ \\
\hline
\end{tabular}

Means followed by the same lower case letters in the columns and lines not statistically different (Tukey P $<0.05$ ).

Table 11. Yield of whole grain on the upland rice according on the cultivar and growing environment.

\begin{tabular}{crr}
\hline Cultivars & & Municipalities \\
\cline { 3 - 3 } Ecco & Cerejeiras & $51.1 \mathrm{bB}$ \\
AN Cambará & $61.4 \mathrm{aA}$ & $54.95 \mathrm{aA}$ \\
\hline
\end{tabular}

Means followed by the same lower case letters in the columns and lines not statistically different (Tukey P $<0.05$ ). 
Table 12. Yield of whole grain on the upland rice according of the growing environment and doses of nitrogen, phosphorus and potassium (N-P-K).

\begin{tabular}{cccccc}
\hline \multirow{2}{*}{ Municipalities } & \multicolumn{5}{c}{ Doses of N-P-K $\left(\mathrm{kg} \cdot \mathrm{ha}^{-1}\right)$} \\
\cline { 2 - 6 } & $00-00-00$ & $30-40-30$ & $60-60-60$ & $90-90-90$ & $120-100-120$ \\
Cerejeiras & $59.25 \mathrm{aA}$ & $58.75 \mathrm{aA}$ & $57.12 \mathrm{aA}$ & $59.92 \mathrm{aA}$ & $61.12 \mathrm{aA}$ \\
Vilhena & $55 \mathrm{bA}$ & $50.62 \mathrm{bA}$ & $54.87 \mathrm{aA}$ & $50.12 \mathrm{bA}$ & $54.5 \mathrm{bA}$ \\
\hline
\end{tabular}

Means followed by the same lower case letters in the columns and lines not statistically different (Tukey P $<0.05$ ).

In the municipality of Cerejeiras, the soil has a higher cation exchange capacity (CTC) and higher organic matter content, as shown in Table 1. In [16], soils with higher organic matter content and CTC greater than 60 mmol dm-3 are more effective in retaining water and nutrients. According to [17] Crusciol in addition to the genetic factor, which influences the loss of grain quality are the periods of water stress that the plant pass during the cycle. Thus, probably, this greater efficiency in water and nutrient retention probably resulted in better performance of whole grains as a function of fertilizers employed in this municipality (Table 12).

The best response to fertilization employed observed in the hybrid Ecco, associated with higher yield of whole grains, are quite relevant factors, due to higher economic return afforded to the producer.

\section{Conclusions}

The hybrid Ecco has higher tillering ability of the AN Cambara and presents fewer sterile grains per panicle, heavier 1000 grains and hence greater productivity.

For both cultivars, the highest productivity is obtained with a dose of $120-100-120 \mathrm{~kg} \cdot \mathrm{ha}{ }^{-1} \mathrm{~N}-\mathrm{P}-\mathrm{K}$. For the Ecco, the productivity is achieved with this dose and the dose of $90-90-90 \mathrm{~kg} \cdot \mathrm{ha}^{-1}$ is statistically similar.

There is no difference in productivity between the municipalities when the dose of N-P-K is less than 60-60$60 \mathrm{~kg} \cdot \mathrm{ha}^{-1}$.

The highest yield of whole grains in function of N-P-K fertilization is obtained in Cerejeiras.

\section{Acknowledgements}

The Empresa Brasileira de Pesquisa Agropecuária (EMBRAPA), the Rack—Industry and Trade of Rice Ltda. $\left(\right.$ RICAL $\left.^{\circledR}\right)$ and the RiceTec ${ }^{\circledR}$.

\section{References}

[1] Fageria, N.K. and Oliveira, J.P. (2014) Nitrogen, Phosphorus and Potassium Interactions in Upland Rice. Journal of Plant Nutrition, 37, 1586-1600. http://dx.doi.org/10.1080/01904167.2014.920362

[2] Guimarães, C.M. (2006) Rice Cultivation in Brazil. 2th Edition, Embrapa Arroz e Feijão, Santo Antônio de Goiás.

[3] Fageria, N.K. and Baligar, V.C. (2001) Improving Nutrient Use Efficiency of Annual Crops in Brazilian Acid Soils for Sustainable Crop Production. Communications in Soil Science and Plant Analysis, 32, 1303-1319. http://dx.doi.org/10.1081/CSS-100104114

[4] CONAB - Companhia Nacional de Abastecimento (2013) Brasilian Crop Assessment: Grains, Twelfth Assessment, September.

http://www.conab.gov.br/OlalaCMS/uploads/arquivos/13_10_16_14_32_01_boletim_ingles_-_setembro_2013.pdf

[5] EMBRAPA—Empresa Brasileira de Pesquisa Agropecuária (2012) http://ainfo.cnptia.embrapa.br/digital/bitstream/item/69387/1/seriedocumentos-268.pdf

[6] Gitti, D.C., Arf, O., Portugal, J.R., Corsini, D.C.D.C, Rodrigues, R.A.F. and Kaneco, F.H. (2013) Cover Crops, Nitrogen Rates and Seeds Inoculation with Azospirillum brasilense in Upland Rice under No-Tillage. Bragantia, 71, 509517. http://dx.doi.org/10.1590/S0006-87052013005000002

[7] CONAB - Companhia Nacional de Abastecimento (2014) Brasilian Crop Assessment: Grains, Eleventh Survey Assessment, August.

http://www.conab.gov.br/OlalaCMS/uploads/arquivos/14_08_07_08_59_54_boletim_graos_agosto_2014.pdf

[8] Soares, E.R., Baseggio, E.A., Londrero, L.S., Correa, S.C.S., Rossini, V.P., Zo-linger, I.T, Klahold, C.A. and Galon, L. (2010) Production and Productivity Components of Hybrid Rice Dry Com-Pared to Conventional Three Cultivars. Acta Agronómica, 59, 435-441. 
[9] Soares, E.R., Robertt, F., Londero, L.S., Santos, D.L., Correa, S.C.S., Correa, E.A.S., Santos, R.C., Gomes, A.P, Galon, L., Pires, F.F and Gonçalves, S.S. (2014) Agronomic Performance of Cultivars of Upland Rice in the Southern of the Region of Rondônia, Brazil. Agricultural Sciences, 5, 513-518. http://dx.doi.org/10.4236/as.2014.56053

[10] Nascente, A.S. Kluthcouski, J., Rabelo, R.R., Oliveira, P., Cobucci, T. and Crusciol, C.A.C. (2011) Upland Rice Cultivars Development and Yield Regarding Soil Management. Pesquisa Agropecuária Tropical, 41, 186-192.

[11] Silva, V.A.C., Silva, E.F. and Tabosa, J.N. (2010) Performance of Upland Rice Genotypes in “Zona da Mata” of Pernambuco State. Revista Brasileira de Engenharia Agrícola e Ambiental, 14, 1030-1037. http://dx.doi.org/10.1590/S1415-43662010001000002

[12] Furlan, D.N., Nunes, D.D, Silva, J.M. da, Lobato, L.C.H., Lima, T.R., Assunção, A.G. de. and Pinto, G.C. (2013) Climate and Soybean Yields in the Municipalities of Cherry and Vilhena Located in the Southern Cone of Rondônia. http://www.cbmet.com/cbm-files/14-9e178324fe343881898c4f98651b1a7d.pdf

[13] Pimentel-Gomes, F. (2009) Statistics Course Experimental. 15th Edition, FEALQ, Piracicaba.

[14] Baudron, F. and Ken, E.G. (2014) Agriculture and Nature: Trouble and Strife? Biological Conservation, 170, $232-245$. http://dx.doi.org/10.1016/j.biocon.2013.12.009

[15] Santos, A.B., Stone, L.F., Fageria, N.K., Prabhu, A.S., Mah, M.G.C., Aquino, A.R.L., Ajimura, G.M., Barbosa Filho, M.P., Zimmermann, F.J.P., Carvalho, J.R.P., Oliveira, A.B. and Silveira Filho, A. (1982) Effect of Different Technology Combinations of Upland Rice Production System. PAB, 17, 835-845.

[16] Lopes, A.S. and Guimarães Guilherme, L.R. (2004) Interpretation of Analysis of Soil. Concepts and Applications, National Association for Diffusion of Fertilizers (ANDA). http://www.anda.org.br/multimidia/boletim_02.pdf

[17] Crusciol, C.A.C, Machado, J.R., Arf, O. and Rodrigues, R.A.F. (1999) Percentage of Undamaged Grains and Hulling Yield of Dryland Rice as Affected by Row and Plant Population. Scientia Agricola, 56, 47-52. http://dx.doi.org/10.1590/S0103-90161999000100008 